Original research article

\title{
Type D personality, clinical characteristics and working life among cancer survivors
}

\author{
Siti Raba'ah Hamzah ${ }^{1 *}$, Zulaiha Muda ${ }^{2}$, Siti Nur Syuhada Musa ${ }^{1}$, Abu Bakar Mohamed Razali ${ }^{1}$ \\ ${ }^{1}$ Universiti Putra Malaysia, Faculty of Educational Studies, Serdang, Selangor, Malaysia \\ ${ }^{2}$ Kuala Lumpur Hospital, Institute of Paediatrics, Kuala Lumpur, Malaysia
}

\begin{abstract}
The purpose of this study was to investigate the association of Type D personality with demographic factors and various clinical characteristics, as well as the relationship of Type D personality with the quality of working life among adult childhood cancer survivors. A cross-sectional survey was conducted from 1st September 2018 until 1st September 2019. The participants were working adult childhood cancer survivors who were undergoing hospital follow-up sessions. Type D personality was assessed using the Type D scale, while the quality of working of life was evaluated using the Quality of Working Life Questionnaire for Cancer Survivors. Descriptive statistics, independent-samples $t$-tests, one-way analysis of variance and bivariate correlations were used to analyse the data collected. Among the adult childhood cancer survivors, 25.3 percent were found to have Type D personality. The study results showed the association of Type D personality with employment status $[F(2,66)=3.27, p=0.028]$ and the number of cancer diagnoses performed $[t(67)=-3.89$, $p=0.000$ ]. Type $\mathrm{D}$ personality was also associated with decreased quality of working life $(r=-0.289, n=69, p<0.05)$. This investigation, the first to assess Type D personality among adult childhood cancer survivors in Malaysia, offers new knowledge that can be used to help practitioners design intervention strategies to curb damaging psychological tendencies among this group, and improve their emotional and social wellbeing.
\end{abstract}

Keywords: Cancer survivors; Clinical characteristics, Quality of working life; Type D personality

\section{Introduction}

Working life environment is often associated with stressful experiences (Bhui et al., 2016). For adult childhood cancer survivors to perform to the best of their ability at the work place, it is essential that they are able to handle stress effectively. A number of factors have been found to influence the stress level of cancer survivors who exhibit various clinical characteristics (Husson et al., 2013). A personality construct which has been shown to have substantial impact on behaviour, health and stress but which has not been frequently studied as a specific group such as cancer survivors is the distressed or Type D personality. The present study was carried out to address this research gap. We used a cross-sectional design to investigate how clinical characteristics and Type D personality might affect the working life of cancer survivors in Malaysia. Individuals with Type D personality are characterised by both the tendency to experience negative emotions and the propensity to inhibit self-expression in social interaction due to their negative and pessimistic views of life in general (Denollet, 2005; Kanten et al., 2017). In addition, cancer survivors with Type D personality seem to have more comorbid conditions and lower health-related quality of life (Mols et al., 2012). To the best of the researchers' knowledge, this issue has yet to be investigated in the Malaysian context. Thus, this study might yield important findings that would be useful to caregivers and healthcare practitioners.

Based on the national Cancer Registry Report of 20122016, nearly 115,000 new cancer cases and more than 80,000 cancer deaths were reported in Malaysia. At the same time, there was an increase in the survival rate of cancer patients. According to the Malaysia National Registry Department of the National Cancer Institute, the survival rate in 2018 was higher in women and the younger patients aged $15-44$ years who comprised $21 \%$ of the sample. The report also revealed that the cancer survival rate was similar to that of other Asian countries (Malaysia National Cancer Registry Report 2012-2016, 2019). Since 2007, all states in Malaysia have set up regional population-based cancer registries. In addition, the Malaysian National Strategic Plan for Cancer Control Programme 20162020 (Ministry of Health Malaysia, 2017) outlined the seven strategies promulgated by the World Health Organization (WHO) for cancer control, including vaccination against hepatitis B in the prevention of liver cancer in 1989, and human papillomavirus vaccination in 2013 to prevent cervical cancer.

\footnotetext{
* Corresponding author: Siti Raba'ah Hamzah, Universiti Putra Malaysia, Faculty of Educational Studies, 43400 UPM Serdang, Selangor, Malaysia; e-mail: srh@upm.edu.my http://doi.org/10.32725/kont.2021.033 
In a study that examined the relationship between Type D personality and cancer survivorship, Husson et al. (2013) found that Type D survivors felt they received less information about their disease and treatment when compared to the nonType D. This was attributed to Type D cancer survivors' unwillingness to make their presence felt and they often avoid social interaction. Survivors with Type D personality tend to experience increased levels of pain and fatigue (Zhang et al., 2016), and thus have a poorer quality of life and fewer prospects in their career advancement compared to the non-Type D (Pedersen and Denollet, 2003). For example, in a case study of a Malaysian breast cancer survivor, it was found that she had feelings of helplessness and even wondered whether life was worth living, essentially depicting a Type D personality (Wan Adnan et al., 2019). Those with Type D personality have been described as having the tendency to experience negative affectivity and social inhibition (Denollet, 2005). Previous studies have shown Type D personality to be an important predictor of health-related quality of life and disease-specific health status beyond clinical characteristics (Denollet et al., 2010; Mols and Denollet, 2010), and this trait might possibly lead to poor behaviours (Denollet, 2005). Most of such studies to date have focused on the middle-aged ( $\mathrm{Ng}$ et al., 2017; Subramaniam et al., 2018), and limited information is available to address the needs of the younger population. In addition, studies on Type D personality tend to focus on specific at-risk sub-populations and are frequently conducted in Western countries. A study in Malaysia revealed that older cancer survivors reported a lower prevalence of anxiety and depression compared to younger patients a year after diagnosis (Subramaniam et al., 2018). Hence it is important to conduct more research among younger cancer survivors in a non-Western setting.

A study by de Jong et al. (2016) indicated that cancer survivors' quality of working life was associated with health and work-related variables.

They found that cancer survivors who underwent chemotherapy had significantly lower quality of working life scores. Moreover, non-managerial cancer survivors with low incomes or physically demanding work, and those who worked on contract, also had significantly lower quality of working life scores. In view of these findings, it is important to adopt appropriate measures to address the causative factors of the quality of working life of adult childhood cancer survivors. Many of the cancer-related questionnaires available today do not adequately address the quality of working life and careers of cancer survivors. The results from the present study could, therefore, offer suggestions for improving cancer survivors' quality of working life and well-being, as well as accommodate the demands of employers and organizations. The findings of this study would add to the literature regarding factors that affect the working life of different groups of cancer survivors, especially those in Malaysia. The study would provide guidelines for more efficient development models that balance the physical, emotional, and social health needs of employees.

\section{Materials and methods}

\section{Study design and participants}

A cross-sectional design was employed to investigate the association of Type D personality with clinical characteristics and quality of working life among adult childhood cancer survivors. Data collection was based on the list of children from birth to 18 years who were diagnosed with cancer and were still on treatment or attending follow up sessions in the
Paediatric Institute, Hospital Kuala Lumpur from 2015 to 2019. Data were collected from 1st September 2018 until 1st September 2019 via self-report questionnaires. Inclusion criteria were set as: (a) cancer survivors who had been diagnosed with cancer (all types) and 18-39 years of age; (b) respondents who were undergoing regular follow-up checks once a year at the Paediatric Institute, Hospital Kuala Lumpur; and (c) respondents who were employed. A total of 400 survivors were eligible for the study but only 273 survivors were included in the analysis undertaken within the data collection period. Those who were left out of the study were 127 survivors who could not be traced from follow-up records and those who declined to participate.

Of the 273 adult childhood cancer survivors ( $M$ age $=25.6$ years), $48.7 \%$ were male and $51.3 \%$ female. Sixty-nine (25.3\%) of them (42.0\% male and $58.0 \%$ female) of mean age 25.04 were classified as having Type $\mathrm{D}$ personality (Table 1 ). In this sample, $46.4 \%$ held permanent jobs, $23.2 \%$ had temporary employment and $30.4 \%$ were self-employed. The data also revealed that $60.9 \%$ of the participants had leukaemia lymphoma, $13.0 \%$ had been afflicted with brain tumour, and $26.1 \%$ with other solid tumours. A total of $84.1 \%$ of participants with Type $\mathrm{D}$ personality were diagnosed only once, and $15.9 \%$ more than once. The cancer treatments that the participants had undergone were surgery (8.7\%), radiotherapy (5.8\%), chemotherapy (47.8\%), surgery and radiotherapy (1.4\%), surgery and chemotherapy (5.8\%), radiotherapy and chemotherapy (14.5\%), as well as surgery, radiotherapy and chemotherapy (14.5\%).

After the Clinic at the Paediatric Institute, Hospital Kuala Lumpur, had compiled a list of cancer survivors, calls were made to prospective respondents to invite them to participate in the study. Most of them agreed to have the meeting on the same day as their appointment with the clinic. After they were briefed about the purpose of the study, they gave their written consent and each received a bilingual (Malay and English) questionnaire. Respondents who completed the questionnaires were given a souvenir as a token of appreciation. Approval to conduct the study was granted by the Medical Ethics Committee (MREC), Ministry of Health, Malaysia, and the National Medical Research Registry (NMRR-18-1895-40225).

\section{Measures}

The items in the questionnaire solicited data related to demographics and clinical-related information, e.g., gender, age, educational level, employment status, initial cancer diagnosis, types of cancer, number of cancer diagnoses, and cancer treatment. The instrument used to assess Type $\mathrm{D}$ personality in this study, D scale-14, was adapted from Denollet (2005). Type D personality refers to the joint tendency towards (a) negative affectivity, which subsumes negative emotions in general, including instances of depression, sadness and nervousness, and (b) social inhibition which holds an individual back from socialising. Having been validated in several countries, the measurement scale by Denollet (2005) is regarded as valid and reliable, with a reported Cronbach alpha of 0.86-0.88. Responses to the questionnaire were scored using a 5-point Likert scale ( 0 - false, 1 - somewhat false, 2 - neutral, 3 - somewhat true and 4 - true). Cronbach's alpha at 0.893 indicated that the instrument was reliable and valid for the evaluation of Type D personality in this study. Participants with scores higher than 10 out of 28 on both subscales of the questionnaire were classified as having Type D personality (Denollet, 2005). Cancer specific quality of working life was assessed using the Questionnaire for Cancer Survivors (QWLQ-CS) with 23 items that 
were developed by de Jong et al. (2016). The original questionnaire was specifically for cancer survivors who were employed by an organisation or who were self-employed. All the items for this scale were rated on a 5-point Likert scale ranging from 1 (strongly disagree) to 5 (strongly agree). The internal reliability of this instrument was determined by Cronbach's coefficient alpha. A high coefficient alpha of 0.91 had been obtained in the original instrument of de Jong et al. (2016).

\section{Data analyses}

The collected data were analysed using the Statistical Package for Social Science (SPSS) version 24.0. After screening for outliers and normality, Cronbach alpha and descriptive statistics for all study variables were obtained. The demographics data for descriptive statistics, frequency, percentage, mean and standard deviation were analysed. Further analyses included the independent sample $t$-test to compare the means of two independent groups (e.g., gender, educational level, number of cancer diagnoses). Next, a one-way between-group analysis (ANOVA) was applied to test for statistically significant differences between the means of independent groups (e.g., for employment status, initial cancer diagnoses, type of cancer and cancer treatment). The Pearson's product-moment correlation was performed to determine the relationships among the variables. This study used the respondents' scores for classification of Type D personality (Denollet, 2005). Following classification of the participants for Type D personality, only data from those identified as adult childhood cancer survivors were used in further analysis. This eventually resulted in a sample consisting of 69 participants with Type D personality.

\section{Results}

This study investigated the association of Type D personality with demographics and clinical characteristics, as well as the relationship of Type $\mathrm{D}$ personality with quality of working life among adult childhood cancer survivors in Malaysia. Table 1 shows that there were no differences among the non-Type D participants in all the variables studied. On the other hand, differences were detected in some of these variables among participants who exhibited Type D personality.

With regard to employment status, participants were divided into three groups (permanent position, temporary employment and self-employed). From the results of the one-way between-group analysis (ANOVA), there was a statistically significant difference at the $p<0.05$ level in Type D personality scores for the three employment statuses $[F(2,66)=3.27$, $p=0.028]$. Despite reaching statistical significance, the actual difference in mean scores between the groups was only moderate. The effect size, calculated using eta squared was 09 . Post-hoc comparisons using Tukey HSD test indicated that the mean score for group 1 (permanent position) $(M=11.76$, $S D=1.81)$ and group 2 (temporary employment) $(M=13.57$, $S D=2.57$ ) was significantly different. Group 3 (self-employed) $(M=12.47, S D=1.94)$ was not significantly different from either group 1 or group 2.

An independent sample $t$-test was conducted to compare Type D personality scores in relation to the number of cancer diagnoses scores for one or more than one diagnoses. There was a significant difference in the scores for a single cancer diagnosis $(M=12.01, S D=1.75)$ and multiple cancer diagnoses $[M=14.6, S D=2.85 ; t(67)=-3.89, p=0.000$, two-tailed $]$. The magnitude of the differences in the means $(M=-2.58$,
95\% CI: -3.91 to -1.26 ) can be considered very large (eta squared $=0.29)$ according to Cohen (1988).

Based on the ANOVA, three investigated variables, viz. the most recent cancer diagnosis $[F(3,65)=1.37, p=0.225]$, three types of cancers $[F(2,66)=4.88, p=0.131]$ and six types of cancer treatments $[F(6,61)=1.36, p=0.629]$ did not reach statistical significance. Similarly, $t$-tests showed no significant difference in Type $\mathrm{D}$ personality scores between male $(M=$ $12.78, S D=2.22$ ) and female survivors $[M=12.32, S D=2.67$; $t(67)=0.940, p=0.760$, two tailed]. The magnitude of the differences in means (mean difference $=458,95 \% \mathrm{CI}:-0.760$ to 1.66 ) was very small (eta squared $=0.013$ ). The results also showed there was no significant difference in two levels of education $[F(2,66)=1.27, p=0.721]$.

Bivariate analysis using the Pearson Product-Moment Correlation was conducted to examine the relationship of Type D personality with quality of working life. In addition, Cohen's categorization of effect size was used to interpret the strength of the correlation between the study variables (Cohen, 1988). Table 2 depicts a small negative correlation between the quality of working life and Type D personality $(r=-0.289, p<0.05)$.

\section{Discussion}

This study examined the association of Type D personality with demographics and clinical characteristics, as well as the relationship of Type D personality with quality of working life. These results highlight the influence of latent cancer-related effects on Type D personality of adult childhood cancer survivors and their impact on the quality of working life. The present findings support the use of the DS-14 instrument to assess universal traits among adult childhood cancer survivors in relation to quality of working life and clinical characteristics. The findings of this study revealed that among adult childhood cancer survivors, the prevalence of those with Type D personality was $25.3 \%$. This is somewhat higher as compared with $19 \%$ reported in a study by Mols et al. (2012) on 3,977 colorectal cancer survivors, but lower than $28 \%$ of those classified as Type D among coronary heart disease patients (Denollet et al., 2000). Type D personality is associated with negative affectivity and social inhibition, and both are relevant to this research context (Mols et al., 2012). The results from this study add a psychological dimension to findings implicating various clinical characteristics (Gegechkori et al., 2017; Sun et al., 2016) with increased risk for a wide range of adverse health outcomes (Mertens et al., 2001) following sessions of treatment (Kunst et al., 2009). According to Denollet and Kupper (2015), many individuals with Type D personality display subclinical levels of emotional distress all their lives.

Respondents from the present study were from a sample of cancer survivors who had received treatment during childhood for leukaemia lymphoma, brain tumour and other solid tumours. It was conducted at the Paediatric Institute, Hospital Kuala Lumpur, which is the centre of excellence and national referral centre in all areas of paediatric services, advocating and promoting child health, providing and supporting training and research pertaining to child health. Furthermore, the Paediatric Institute in Hospital Kuala Lumpur is the primary treatment centre for childhood cancer in Malaysia, and patients come from all over Malaysia. Moreover, Hospital Kuala Lumpur is now the largest hospital under the Ministry of Health of Malaysia and is considered to be the one of the biggest in Asia. 
Table 1. Demographics and clinical characteristics of the respondents and the results of $t$-tests and ANOVA

\begin{tabular}{|c|c|c|c|c|}
\hline Demographics/clinical characteristics & $\begin{array}{c}n(\%) \\
\text { Type D } \\
\text { personality } \\
69(25.3 \%)\end{array}$ & $p$-value & $\begin{array}{c}n(\%) \\
\text { Non-Type D } \\
\text { personality } \\
204(74.7 \%)\end{array}$ & $p$-value \\
\hline $\begin{array}{l}\text { Gender } \\
\text { Male } \\
\text { Female }\end{array}$ & $\begin{array}{l}29(42.0) \\
40(58.0)\end{array}$ & 0.458 & $\begin{array}{l}104(51.0) \\
100(49.0)\end{array}$ & 0.405 \\
\hline $\begin{array}{l}\text { Age } \\
\qquad \begin{array}{l}18-23.5 \\
24-29.5 \\
30-35.5 \\
36-40\end{array}\end{array}$ & $\begin{array}{c}32(46.3) \\
23(33.3) \\
9(13.0) \\
5(7.4)\end{array}$ & 0.087 & $\begin{array}{l}97(47.5) \\
64(31.3) \\
25(12.4) \\
18(8.8)\end{array}$ & 0.597 \\
\hline $\begin{array}{l}\text { Educational level } \\
\text { Medium (general or basic education) } \\
\text { High (pre-university and university) }\end{array}$ & $\begin{array}{l}21(30.4) \\
48(69.6)\end{array}$ & 0.721 & $\begin{array}{c}76(37.3) \\
128(62.7)\end{array}$ & 0.711 \\
\hline $\begin{array}{l}\text { Employment status } \\
\text { Permanent position } \\
\text { Temporary employment } \\
\text { Self-employed }\end{array}$ & $\begin{array}{l}32(46.4) \\
16(23.2) \\
21(30.4)\end{array}$ & $0.028^{*}$ & $\begin{array}{l}92(45.1) \\
39(19.1) \\
73(35.8)\end{array}$ & 0.200 \\
\hline $\begin{array}{l}\text { Initial cancer diagnosis } \\
\quad<5 \text { years } \\
6-10 \text { years } \\
11-15 \text { years } \\
>16 \text { years }\end{array}$ & $\begin{array}{c}8(11.6) \\
9(13.0) \\
19(27.5) \\
33(47.8)\end{array}$ & 0.225 & $\begin{array}{l}21(10.3) \\
37(18.1) \\
55(27.0) \\
91(44.6)\end{array}$ & 0.441 \\
\hline $\begin{array}{l}\text { Type of cancer } \\
\text { Leukaemia lymphoma } \\
\text { Brain tumour } \\
\text { Other solid tumours }\end{array}$ & $\begin{array}{c}42(60.9) \\
9(13.0) \\
18(26.1)\end{array}$ & 0.131 & $\begin{array}{l}130(63.7) \\
21(10.3) \\
53(26.0)\end{array}$ & 0.405 \\
\hline $\begin{array}{l}\text { Number of cancer diagnoses } \\
\text { Once } \\
\text { More than once }\end{array}$ & $\begin{array}{l}58(84.1) \\
11(15.9)\end{array}$ & $0.000^{*}$ & $\begin{array}{c}187(91.7) \\
17(8.3)\end{array}$ & 0.741 \\
\hline $\begin{array}{l}\text { Cancer treatment } \\
\text { Surgery } \\
\text { Radiotherapy } \\
\text { Chemotherapy } \\
\text { Surgery and Radiotherapy } \\
\text { Surgery and Chemotherapy } \\
\text { Radiotherapy and Chemotherapy } \\
\text { Surgery Radiotherapy and Chemotherapy }\end{array}$ & $\begin{aligned} 6 & (8.7) \\
4 & (5.8) \\
33 & (47.8) \\
1 & (1.4) \\
4 & (5.8) \\
10 & (14.5) \\
10 & (14.5)\end{aligned}$ & 0.629 & $\begin{array}{c}11(5.4) \\
4(2.0) \\
85(41.7) \\
4(2.0) \\
27(13.2) \\
24(11.8) \\
44(21.6)\end{array}$ & 0.105 \\
\hline
\end{tabular}

Table 2. Bivariate correlations between quality of working life and Type $D$ personality among cancer survivors $(n=69)$

\begin{tabular}{lcccc}
\hline Variable & Mean & SD & $\begin{array}{c}\text { Type D } \\
\text { personality }\end{array}$ & $\begin{array}{c}\text { Quality } \\
\text { of } \\
\text { working } \\
\text { life }\end{array}$ \\
\hline Type D personality & 1.77 & 0.305 & 1.00 & \\
\hline Quality of working life & 3.49 & 0.519 & $-0.289^{*}$ & 1.00 \\
\hline
\end{tabular}

Notes: ${ }^{*}$ Correlation is significant at the 0.05 level (2-tailed).

Despite their health situation, almost 70 percent of adult childhood cancer survivors continued with their studies and achieved pre-university and university level of education. Nevertheless, as survivors may also be adversely affected by missing time in school due to treatment (Vance and Eiser, 2002), interventions to address educational difficulties are introduced in some settings. In Malaysia, the Ministry of Education allows patients, including cancer patients, to attend special classes in the hospital and to sit for their examination while undergoing treatment in the hospital.

Our results support previous findings that being employed is important to the well-being of cancer survivors. Employment status among cancer survivors is beneficial in multiple quality of life domains, whereas work-related factors can act as barriers to resuming work in the same way as before (Islam et al., 2014). Differences in the degree of Type D personality were manifested most clearly between survivors in full-time employment and those who were temporarily employed. A study on breast cancer survivors found that overall well-being was higher for women who continued working compared to women who stopped working or were not working (Timperi et al., 2013).

The literature on early cancer diagnosis shows that the period from the first signs to diagnosis appears to be a key determinant of cancer outcomes (Walter et al., 2012). The results of this study indicated that the majority of the respondents with Type D personality were diagnosed only once (84.1\%). Therefore, understanding the factors associated with Type D personality would allow the social support system to provide 
related resources and services to cancer survivors at the right time.

Among the adult childhood cancer survivors in our study, nearly 61 percent had lymphoma leukaemia and Type D personality. Lymphoma leukaemia is the most common malignancy of childhood, accounting for nearly 30 percent of all childhood cancers (Young et al., 2000); those who contract this disease are at risk to late effects of cancer therapy such as more severe chronic medical conditions, activity limitations, and functional impairment (Mody et al., 2008).

The finding that cancer diagnoses are significantly related to Type D personality is consistent with those of previous studies which report that cancer diagnosis and cancer treatment are associated with emotional distress (Brinkman et al., 2013). Research has shown that individuals who are diagnosed with cancer can fall into a state of depression and anxiety, thus resulting in their mental health being affected (Pitman et al., 2018).

A bivariate correlation in the present study showed a negative correlation between Type D personality with quality of working life. Hence, the greater the degree of Type D personality, the lesser the quality of working life that was experienced by the respondents. This finding supports previous research by Mols and Denollet (2010) regarding the association between Type D personality and impaired health status that may also have an impact on health problems at the workplace (Ogińska-Bulik, 2006). Survivors are more likely to develop post-traumatic stress disorder when they are confronted with significant stressors at work (Kunst et al., 2009).

As indicated by our results, it is important to pay attention to both clinical characteristics and quality of working life variables of childhood cancer survivors. Although a change in personality is difficult, modification of quality of working life factors is possible. Hence, there should be appropriate interventions to enhance participation of adult childhood cancer survivors at the workplace. This should be a consideration of policymakers, public health professionals and clinicians when formulating strategies for this segment of the workforce.

The present study has several limitations that should be considered while interpreting the results. The cross-sectional design that was used did not allow for the identification of causes and effects of Type D personality and clinical characteristics, and how working life changes over time among cancer survivors. In particular, we were not able to examine whether Type D personality symptoms and clinical characteristics effects had already existed prior to cancer diagnosis. Secondly, we conducted our study with a sample from adult childhood cancer survivors. Hence, the findings cannot be generalized to reflect other categories of cancer survivors.
Despite these limitations, this study contributes to the literature, and is, to the best of our knowledge, the first study on Malaysian adult childhood cancer survivors with Type D personality and the quality of their working life. Perhaps future research on Type D personality among cancer survivors could be a longitudinal study.

\section{Conclusions}

Paying special attention to cancer survivors with Type D personality is important as their working life is likely to be adversely impacted by their health status. The results of this study confirm that the quality of working life has a negative relationship with Type D personality. Identification of Type D personality among cancer survivors is important as they are at increased risk of being mentally and emotionally affected at the workplace. In view of the limited data available on this segment of employees, the present study provides a useful insight from a behavioural research perspective of Type $\mathrm{D}$ personality among Malaysian adult childhood cancer survivors. Nevertheless, further research along these lines among various cancer survivors over a longer period of time would be more insightful. This study also offers new knowledge on Type D personality that can be used to help design intervention strategies to minimize harmful health effects as well as to improve the emotional and social wellbeing of childhood cancer survivors.

Cancer survivors should be made aware of the opportunities available at the workplace that can improve their well-being. Despite the negative association between quality of working life and Type D personality, the association is rather weak. Therefore, there is room for optimism that cancer survivors can improve their sociological and psychological ability to cope with the stress and adversity facing them. It is also important for health care providers to be aware that the problems faced by childhood cancer survivors may not be similar to the ones experienced by other cancer survivors.

\section{Ethical aspects and conflict of interests}

The authors declare that they have no competing interests in conducting this study.

\section{Acknowledgements}

The authors gratefully acknowledge the funding support provided by the Ministry of Higher Education Malaysia (2018-2020), Universiti Putra Malaysia (UPM/700-2/1/ GPB/2017/9597500). 


\section{Osobnost typu D, klinické charakteristiky a pracovní život u osob, které přežily rakovinu}

\section{Souhrn}

Cílem této studie bylo zjistit souvislosti výskytu osobnosti typu D s demografickými faktory a různými klinickými charakteristikami, jakož i vztah mezi osobností typu D a kvalitou pracovního života u dospělých osob, které v dětství přežily rakovinu. Průřezový průzkum byl proveden od 1. září 2018 do 1. září 2019. Respondenti byli pracující dospělí lidé, kteří v dětství přežili rakovinu a kteři absolvovali následná nemocniční sezení. Osobnost typu D byla hodnocena pomocí škály pro osobnosti typu D, zatímco kvalita pracovního života byla hodnocena pomocí dotazníku Quality of Working Life Questionnaire for Cancer Survivors. K analýze shromážděných údajů byla použita deskriptivní statistika, $t$-testy nezávislých vzorků, jednosměrná analýza rozptylu a bivariační korelace. Mezi dospělými osobami, které přežily v dětství rakovinu, bylo zjištěno, že 25,3 \% z nich má osobnost typu D. Výsledky studie ukázaly souvislosti mezi osobností typu $\mathrm{D}$ a zaměstnaností $[F(2,66)=3,27, p=0,028]$ a počtem onkologických diagnóz $[t(67)=-3,89, p=0,000]$. Osobnost typu D byla také spojena se sníženou kvalitou pracovního života $(r=-0,289, n=69, p<0,05)$. Tato studie, která jako první v Malajsii zkoumala výskyt osobnosti typu D mezi dospělými lidmi, kteří přežili rakovinu v dětství, nabízí nové poznatky, které mohou být využity při navrhování intervenčních strategií pro praktiky s cílem omezit škodlivé psychické tendence u této skupiny obyvatelstva a zlepšit její emoční a sociální pohodu.

Klíčová slova: klinické charakteristiky; kvalita pracovního života; osobnost typu D; osoby, které přežily rakovinu

\section{References}

1. Bhui K, Dinos S, Galant-Miecznikowska M, de Jongh B, Stansfeld S (2016). Perceptions of work stress causes and effective interventions in employees working in public, private and non-governmental organisations: A qualitative study. BJPsych Bull 40(6): 318-325. DOI: 10.1192/pb.bp.115.050823.

2. Brinkman TM, Zhu L, Zeltzer LK, Recklitis CJ, Kimberg C, Zhang N, et al. (2013). Longitudinal patterns of psychological distress in adult survivors of childhood cancer. $\mathrm{Br}$ J Cancer 109(5): 1373-1381. DOI: 10.1038/bjc.2013.428.

3. Cohen J (1988). Statistical Power Analysis for the Behavioral Science. Second Edition. New Jersey: Lawrence Erlbaum Associates, pp. 20-26.

4. de Jong M, Tamminga SJ, de Boer AGEM, Frings-Dresen MHW (2016). Quality of working life of cancer survivors: Development of a cancer-specific questionnaire. J Cancer Surviv 10(2): 394-405. DOI: 10.1007/s11764-015-0485-4.

5. Denollet J (2005). DS14: standard assessment of negative affectivity, social inhibition, and Type D personality. Psychosom Med 67(1): 89-97. DOI: 10.1097/01.psy.0000149256.81953.49.

6. Denollet J, Kupper N (2015). Stress and the heart: The role of type D personality in personalized care. Eur Heart J 36(28): 1783-1785. DOI: 10.1093/eurheartj/ehv248.

7. Denollet J, Schiffer AA, Spek V (2010). A general propensity to psychological distress affects cardiovascular outcomes: Evidence from research on the type D (distressed) personality profile. Circ Cardiovasc Qual Outcomes 3(5): 546-457. DOI: 10.1161/ CIRCOUTCOMES.109.934406.

8. Denollet J, Vaes J, Brutsaert DL (2000). Inadequate response to treatment in coronary heart disease: adverse effects of type $\mathrm{D}$ personality and younger age on 5-year prognosis and quality of life. Circulation 102(6): 630-635. DOI: 10.1161/01. CIR.102.6.630.

9. Gegechkori N, Haines L, Lin JJ (2017). Long-term and latent side effects of specific cancer types. Med Clin North Am 101(6): 1053-1073. DOI: 10.1016/j.mcna.2017.06.003.

10. Husson O, Denollet J, Oerlemans S, Mols F (2013). Satisfaction with information provision in cancer patients and the moderating effect of Type D personality. Psychooncology 22(9): 2124-2132. DOI: 10.1002/pon.3267.

11. Islam T, Dahlui M, Abd Majid H, Nahar AM, Taib NA, Su TT, MyBCC Study Group (2014). Factors associated with return to work of breast cancer survivors: A systematic review. BMC Public Health 14(Suppl. 3): S8. DOI: 10.1186/1471-2458-14-S3S8.

12. Kanten P, Gümüştekin J, Kanten $S$ (2017). Exploring the role of $\mathrm{A}, \mathrm{B}, \mathrm{C}$ and $\mathrm{D}$ personality types on individuals work related behaviors and health problems: A theoretical model. Int J Bus Manag Invent 6(7): 29-37.

13. Kunst MJJ, Bogaerts S, Winkel FW (2009). Peer and inmate aggression, type D-personality and post-traumatic stress among Dutch prison workers. Stress Health 25(5): 387-395. DOI: 10.1002/smi.1247.

14. Malaysia National Cancer Registry Report 2012-2016 (2019). National Cancer Registry Department, National Cancer Institute, Ministry of Health. [online] [cit. 2020-0920]. Available at: https://www.moh.gov.my/moh/resources/ Penerbitan/Laporan/Umum/2012-2016\%20(MNCRR)/ MNCR_2012-2016_FINAL_(PUBLISHED_2019).pdf

15. Mertens AC, Yasui Y, Neglia JP, Potter JD, Nesbit Jr ME, Ruccione K, et al. (2001). Late mortality experience in five-year survivors of childhood and adolescent cancer: The Childhood Cancer Survivor Study. J Clin Oncol 19(13): 3163-3172. DOI: 10.1200/JCO.2001.19.13.3163.

16. Ministry of Health Malaysia (2017). National Strategic Plan for Cancer Control Programme 2016-2020. 1st ed. WP Putrajaya: Ministry of Health Malaysia.

17. Mody R, Li S, Dover DC, Sallan S, Leisenring W, Oeffinger KC, et al. (2008). Twenty-five-year follow-up among survivors of childhood acute lymphoblastic leukemia: A report from the Childhood Cancer Survivor Study. Blood 111(12): 5515-5123. DOI: 10.1182/blood-2007-10-117150.

18. Mols F, Denollet J (2010). Type D personality in the general population: A systematic review of health status, mechanisms of disease, and work-related problems. Health Qual Life Outcomes 8(9): 1-10. DOI: 10.1186/1477-7525-8-9.

19. Mols F, Denollet J, Kaptein AA, Reemst PHM, Thong MSY (2012). The association between Type D personality and illness perceptions in colorectal cancer survivors: A study from the population-based PROFILES registry. J Psychosom Res 73(3): 232-239. DOI: 10.1016/j.jpsychores.2012.07.004.

20. Ng CG, Mohamed S, Kaur K, Sulaiman AH, Zainal NZ, Taib NA, MyBCC Study group (2017). Perceived distress and its association with depression and anxiety in breast cancer patients. PLoS One 12(3): e0172975. DOI: 10.1371/journal. pone.0172975.

21. Ogińska-Bulik N (2006). Occupational stress and its consequences in healthcare professionals: The role of type D personality. Int J Occup Med Environ Health 19(2): 113-22. DOI: 10.2478/v10001-006-0016-7.

22. Pedersen SS, Denollet J (2003). Type D personality, cardiac events, and impaired quality of life: A review. Eur J Cardiovasc Prev Rehabil 10(4): 241-248. DOI: 10.1097/00149831200308000-00005.

23. Pitman A, Suleman S, Hyde N, Hodgkiss A (2018). Depression and anxiety in patients with cancer. BMJ 361: k1415. DOI: 10.1136/bmj.k1415. 
24. Subramaniam S, Kong YC, Chinna K, Kimman M, Ho YZ, Saat N, et al. (2018). Health-related quality of life and psychological distress among cancer survivors in a middleincome country. Psychooncology 27(9): 2172-2179. DOI: $10.1002 /$ pon.4787.

25. Sun W, Chen K, Terhaar A, Wiegmann DA, Heidrich SM, Tevaarwerk AJ, Sesto ME (2016). Work-related barriers, facilitators, and strategies of breast cancer survivors working during curative treatment. Work 55(4): 783-795. DOI: 10.3233/ WOR-162449.

26. Timperi AW, Ergas IJ, Rehkopf DH, Roh JM, Kwan ML Kushi LH (2013). Employment status and quality of life in recently diagnosed breast cancer survivors. Psychooncology 22(6): 1411-1420. DOI: 10.1002/pon.3157.

27. Vance YH, Eiser C (2002). The school experience of the child with cancer. Child Care Health Dev 28(1): 5-19. DOI: 10.1046/j.1365-2214.2002.00227.x.
28. Walter F, Webster A, Scott S, Emery J (2012). The Andersen Model of Total Patient Delay: A systematic review of its application in cancer diagnosis. J Health Serv Res Policy 17(2): 110-118. DOI: 10.1258/jhsrp.2011.010113.

29. Wan Adnan WNA, Ibrahim NA, Haladin NB, Wan Fakhruddin WFW (2019). Illness Experience Sharing on Personal Blogs: A Case Study of Malaysian Breast Cancer Survivors. GEMA Online ${ }^{\circledR}$ Journal of Language Studies 19(4): 28-47. DOI: 10.17576/gema-2019-1904-02.

30. Young G, Toretsky JA, Campbell AB, Eskenazi AE (2000). Recognition of common childhood malignancies. Am Fam Physician 61(7): 2144-2154.

31. Zhang JK, Fang LL, Zhang DW, Jin Q, Wu XM, Liu JC, et al. (2016). Type D personality in gastric cancer survivors: Association with poor quality of life, overall survival, and mental health. J Pain Symptom Manag 52(1): 81-91. DOI: 10.1016/j.jpainsymman.2015.12.342. 